\title{
Assessing the effect of governing parameters of bearing capacity determination of small piled rafts on clay soil
}

\author{
Shivanand Mali $^{1} \mathbb{D} \cdot$ Baleshwar Singh $^{1}$
}

Received: 3 May 2021 / Accepted: 13 October 2021 / Published online: 31 October 2021

(C) The Author(s) 2021

\begin{abstract}
In the present study, a small piled raft foundation has been simulated numerically through PLAXIS 3-D software. The objective of this study was to investigate the effect of governing parameters such as pile length, pile spacing, pile diameter, and number of piles on the settlement and load-bearing behavior of piled raft, so as to achieve the optimum design for small piled raft configurations. An optimized design of a piled raft is defined as a design with allowable center and differential settlements and satisfactory bearing behavior for a given raft geometry and loading. The results indicated that, with increase in pile length, pile spacing, pile diameter, and number of piles, both the center settlement ratio and differential settlement ratio decreased. The load-bearing capacity of piled raft increased with increase in pile length, pile spacing, pile diameter, and number of piles. Furthermore, the percentage load carried by the piles increased as the pile length, pile spacing, pile diameter, and number of piles increased. The bending moment and shear force in corner pile are noted to be more, and they decreased towards the center pile. With increase in pile length, the maximum raft bending moment decreased, whereas the maximum shear force in the raft increased. Further, with increase in pile spacing, pile diameter, and number of piles, the maximum bending moment and maximum shear force in the raft increased. The optimum parameters for the piled raft foundation can be selected efficiently with the consideration of maximum bending moment and maximum shear force while designing the piled raft foundation. Thus, the results of this study can be used as guidelines for achieving optimum design for small piled raft foundation.
\end{abstract}

Keywords Piled raft $\cdot$ Settlement ratio $\cdot$ Numerical modeling $\cdot$ Clay

\section{Introduction}

Foundation is the most important part of the structure, and hence, it should be analyzed and designed in order to provide safety, reliability, and serviceability of the structure. If the shear strength of clay soil is very poor, long load-bearing piles are required to transfer the entire load to deeper and stiffer soil layers. Moreover, if the shear strength of clay soil is adequate, then load can be supported by the raft foundation. However, when the clay layer has intermediate strength, raft foundation may not be feasible, as the bearing capacity

Responsible Editor: Zeynal Abiddin Erguler

Shivanand Mali

shivanandmali2007@gmail.com;

shivanandmali2008@gmail.com

1 Department of Civil Engineer, Indian Institute of Technology Guwahati, Guwahati 781039, Assam, India may not be adequate, or settlements may be excessive. In such cases, where a raft foundation alone does not satisfy the settlement and bearing criteria, a limited number of piles can be added to enhance its settlement performance and the load-bearing capacity (Maharaj and Gandhi 2004).

The piled raft can be classified into two categories, as "small piled raft" when the raft width is lesser than the pile length $\left(B_{\mathrm{r}}<L_{\mathrm{p}}\right)$, and as "large piled raft" when the raft width is greater than the pile length $\left(B_{\mathrm{r}}>L_{\mathrm{p}}\right)$ (Viggiani 2001). In a small piled raft, the primary reason to add the piles is to achieve a sufficient factor of safety against bearing failure. However, in a large piled raft, piles are added essentially to reduce the settlement. The piled raft has been used for supporting a high rise buildings and offshore structures because it is very efficient in reducing settlement and improving the load-bearing capacity of soil. A few successful applications of piled rafts on soft clay were reported by Sales et al. (2010), and Russo et al. (2013. Ahmed et al. (2014) evaluated the soil-foundation-structure interaction of buildings 
founded on piled raft foundation through PLAXIS 3-D software. They reported that the interaction of building foundation-soil field and superstructure was remarkable effect on the structure.

Nguyen et al. (2014) conducted the parametric study for optimal design of large piled raft foundations on sandy soil through centrifuge test. The study showed that the concentrated pile arrangement method can help to considerably reduce the total and differential settlements as well as the induced bending moments of the raft. Akl et al. (2014) studied the effect of changing configurations and lengths of piles on piled raft foundation behavior on clay soil through FLAC 3-D software. For the same number of piles, the change in piles distribution over the raft area was a slight effect on the piled raft average settlement, while it had a considerable effect on the piled raft differential settlement. Johari et al. (2017) carried reliability analysis of seismic ultimate bearing capacity of strip footing by slip lines method coupled with random field theory. They compared probability density functions of seismic and static bearing capacities to each other. The predicted probability density function (PDF) of the seismic bearing capacity by slip line method is verified, with those of the Terzaghi equation and Monte Carlo simulation (MCs).

Johari and Sabzi (2017) presented reliability-based analysis of strip footing settlement by stochastic finite element method (SFEM). The stochastic response surface method (SRSM) and random finite element method (RFEM) are used as two formulation of SFEM. It was observed that the results of SRSM are close to RFEM; however, the consumed time in RFEM is at most 50 times longer than SRSM. Using the faster method, SRSM, it is concluded that considering the spatial variability of soil parameters in stochastic analysis is necessary. Johari and Talebi (2021) extended the application of random fields to a stochastic analysis of a piled raft foundation embedded into an elastoplastic soil. The stochastic analysis showed that implementation of the uncertainties of soil parameters leads to more influence on the raft differential settlement compared to the other responses. Variation of the horizontal and vertical correlation length has a more considerable effect on the coefficient of variation $(\mathrm{COV})$ of the bored piles' responses compared to those of the raft. Based on the COV, it is demonstrated that the heterogeneity of the soil has more influence on the raft.

Lee et al. (2010) carried a three-dimensional analysis of bearing behavior of piled raft on soft clay with ABAQUS 3-D software. They reported that the use of a limited number of piles, strategically located, might improve both bearing capacity and the settlement performance of the raft. Cho et al. (2012) studied the settlement behavior of piled raft in soft and stiff clay soils for quantifying the reduction of the average and differential settlements. The study indicated that the variation of settlement reduction ratio of soft clay was relatively greater than that of stiff clay. In addition to this, some other numerical studies were carried out on the analysis of a piled raft in clay soil using a 3-D finite element method (Sanctis and Mandolini 2006; Oh et al. 2009).

However, only a few studies have been carried out to examine the effect of governing parameters such as pile length $\left(L_{\mathrm{p}}\right)$, pile spacing $\left(S_{\mathrm{p}}\right)$, pile diameter $\left(d_{\mathrm{p}}\right)$, and number of piles $\left(N_{\mathrm{p}}\right)$, on the settlement and load-bearing behavior of small piled raft foundation on a clay soil. Moreover, the role of above governing parameters in optimal design of a small piled raft foundation is less well documented and needs to be investigated. The objective of present study is to investigate the effect of the above governing parameters on the settlement and load-bearing behavior of piled raft by means of numerical analysis, so as to achieve the optimum design for small piled raft configurations. The optimization of piled raft geometry involves the determination of optimum values of governing parameters, so that the maximum and differential settlements are lower than the allowable values by the least margin, and the load intensity below the raft portion of the piled raft is lower than the safe bearing capacity $\left(q_{\mathrm{s}}\right)$ of the unpiled raft.

\section{Numerical modeling}

In the present study, the behavior of small piled raft was examined by PLAXIS 3-D numerical analysis. The model consists of unaffected soil domain, piled raft geometry, and the applied load $(q)$ of $150 \mathrm{kPa}$. The soil was modeled with 10 -node tetrahedral elements and as following the elasticperfectly plastic Mohr-Coulomb model. Mohr-Coulomb model requires lesser number of input parameter of soil, and also these parameters can be easily found in the laboratory. The parameters required for modeling consisted of cohesion, angle of internal friction, Young's modulus, and Poisson's ratio. As per the Mohr-Coulomb failure criteria, the yielding or failure takes place in the soil mass as the mobilized shear stress at any plane becomes equal to the shear strength of soil.

A raft was placed on the ground surface of soil and water table assumed to be located at a ground surface. The raft and piles were modeled with 5-node triangular plate element and 4-node line elements, respectively. The material of raft and piles were considered to be linear elastically. The piles and raft was connected by rigid connection. The lateral boundaries were placed at a distance of twice the width of raft from the raft edge and restrained against horizontal translation to allow downward movement of the soil. The bottom most horizontal boundary was placed at a depth of twice the width of raft plus maximum length of pile used in the study $\left(L_{\mathrm{pmax}}\right)$ and restricted from both horizontal and vertical translations. The globally fine mesh has been selected for the entire soil 
domain; however, relatively finer mesh was chosen near the structural elements. Figure 1 show the typical finite element mesh used in the present study.

\section{Model validation}

The present finite element model in PLAXIS 3-D has been validated using an example reported by Poulos (2001a). In this example, the soil has been characterized by modulus of elasticity $\left(E_{\mathrm{s}}=20 \mathrm{MPa}\right.$ and Poisson's ratio of $\left(\nu_{\mathrm{s}}\right)=0.3$. Pile and raft Young's modulus, $E_{\mathrm{p}}=E_{\mathrm{r}}=30 \mathrm{GPa}$ have been considered. The comparison of the results of the present study and reported results is shown in Fig. 2. It can be seen that there is a good agreement with the reported results for different number of piles.

\section{Parametric study}

In the current study, a square unpiled raft foundation system of $15 \mathrm{~m}$ width $\left(B_{\mathrm{r}}\right)$ and thickness $\left(t_{\mathrm{r}}\right)$ of $1.5 \mathrm{~m}$, resting on soft clay, has to transmit the uniformly distributed load (UDL) from the superstructure $150 \mathrm{kPa}$. The physical and mechanical properties of soil, raft, and piles are tabulated in Table 1 . The values of $E_{\mathrm{s}}, \nu_{\mathrm{s}}, E_{\mathrm{r}}, t_{\mathrm{r}}$, and $E_{\mathrm{p}}$ have been selected from the guidelines given by Viggiani (2001). Based on the vertical settlement of the raft, the center settlement ratio $\left(W_{\text {ratio }}\right)$ and differential settlement ratio $\left(\Delta W_{\text {ratio }}\right)$ can be determined. The $W_{\text {ratio }}$ is defined as the ratio of center settlement of raft $\left(W_{\mathrm{c}}\right)$ to the allowable maximum settlement $(A M S)$ of the raft. The $\Delta W_{\text {ratio }}$

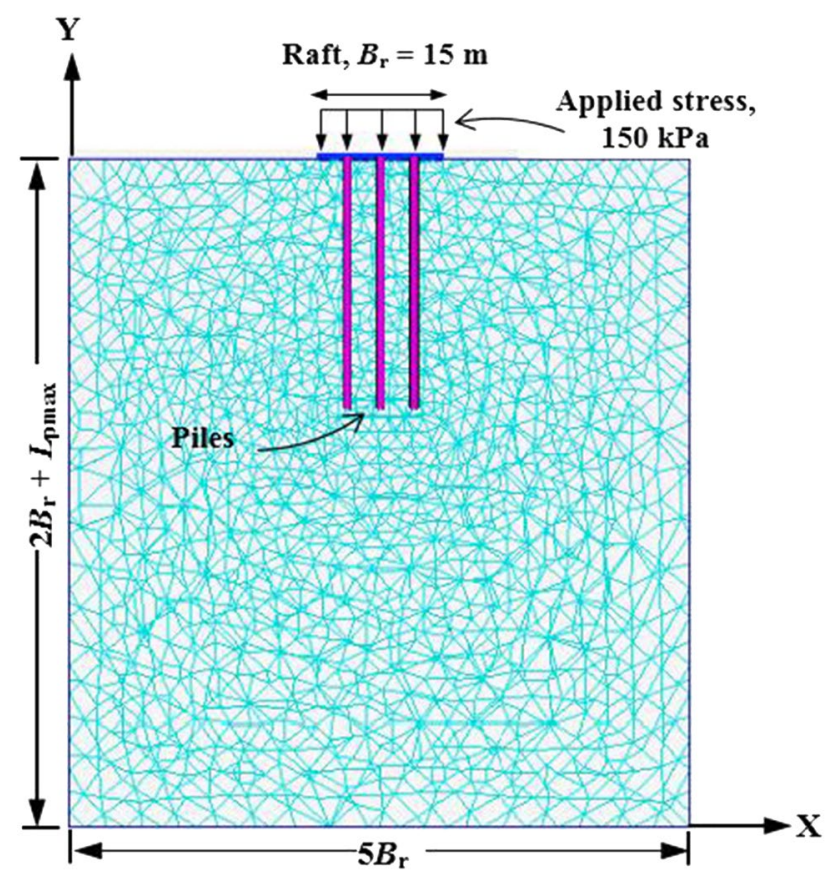

Fig. 1 Typical finite element mesh used in the parametric study

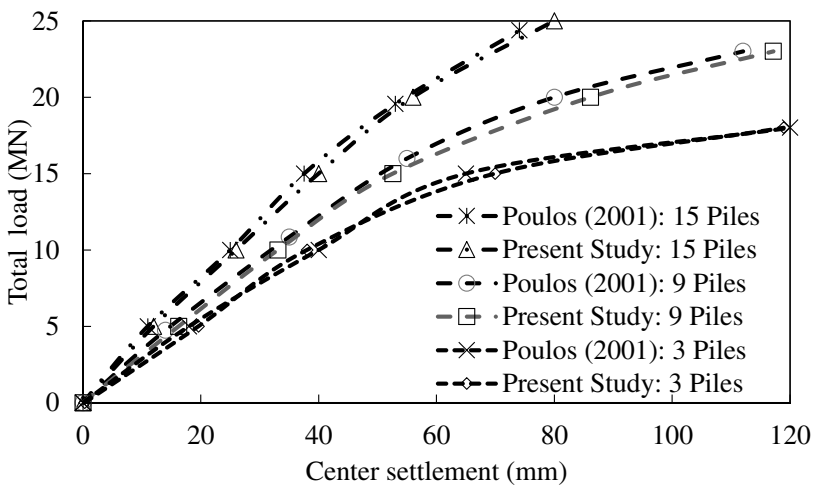

Fig. 2 Comparison of load-settlement behavior between present method and method used by Poulos (2001a) for different number of piles

is considered as the ratio of differential settlement of raft $\left(W_{\mathrm{c-e}}\right)$ to the allowable maximum differential settlement $(A M D S)$ of the raft. The $W_{\text {c-e }}$ is defined as the difference between $W_{\mathrm{c}}$ and edge settlement of the raft $\left(W_{\mathrm{e}}\right)$ to

$W_{\text {ratio }}=\frac{W_{C}}{A M S}$

$\Delta W_{\text {ratio }}=\frac{W_{c-e}}{A M D S}$

As per IS 6403-1981, the ultimate bearing capacity of raft $\left(q_{\mathrm{ur}}\right)$ foundation placed at the soil surface is calculated by the following formula:

$q_{u r}=c_{u} \cdot N_{c} \cdot S_{c} \cdot d_{c} \cdot i_{c}$

where $c_{u}=25 \mathrm{kPa}, N_{c}=$ Bearing capcity factor $=5.14$, $S_{c}=$ Shape factor $=1.3, \quad d_{c}=$ Depth factor $=1$, $i_{c}=$ Inclination factor $=1$

$\therefore q_{u r}=c_{u} \times 5.14 \times 1.3 \times 1 \times 1=6.68 . c_{u}=6.68 \times 25=167.05 \mathrm{kPa}$

Table 1 Material properties used in the numerical modeling

\begin{tabular}{llll}
\hline Material & Properties & Unit & Values \\
\hline Soil & Unsaturated unit weight, $\gamma_{\text {unsat }}$ & $\mathrm{kN} / \mathrm{m}^{3}$ & 16 \\
& Saturated unit weight, $\gamma_{\mathrm{sat}}$ & $\mathrm{kN} / \mathrm{m}^{3}$ & 17 \\
& Young's modulus, $E_{\mathrm{s}}$ & $\mathrm{MPa}$ & 25 \\
& Poisson's ratio, $\nu_{\mathrm{s}}$ & - & 0.495 \\
& Undrained cohesion, $c_{\mathrm{u}}$ & $\mathrm{kPa}$ & 25 \\
& Angle of internal friction, $\varphi$ & $\circ$ & 0 \\
\multirow{2}{*}{ Raft } & Young's modulus, $E_{\mathrm{r}}$ & $\mathrm{GPa}$ & 25 \\
& Poisson's ratio, $\nu_{\mathrm{r}}$ & - & 0.25 \\
Pile & Young's modulus, $E_{\mathrm{p}}$ & $\mathrm{GPa}$ & 25 \\
& Poisson's ratio, $\nu_{\mathrm{p}}$ & - & 0.25 \\
\hline
\end{tabular}


By considering factor of safety (F.O.S) equal to 2.5 , the calculated safe bearing capacity $\left(q_{\mathrm{s}}\right)$ of the raft is as follows.

$q_{s}=\frac{q_{u r}}{F . O . S}=\frac{167.05}{2.5}=66.82 \cong 67 \mathrm{kPa}$

As per IS 1904-1986, the AMS of the raft foundation is $125 \mathrm{~mm}$, whereas the $A M D S$ is $49.5 \mathrm{~mm}\left(0.0033 * B_{\mathrm{r}}\right)$. If only unpiled raft of any $t_{\mathrm{r}}$ is considered, it possesses inadequate $q_{\mathrm{s}}$ of $66.8 \mathrm{kPa}$ at $q=150 \mathrm{kPa}$. In addition to this, at $q=150 \mathrm{kPa}$, the unpiled raft of $t_{\mathrm{r}}=1.5 \mathrm{~m}$ undergoes excessive $W_{\mathrm{c}}(913 \mathrm{~mm})$ and $W_{\mathrm{c}-\mathrm{e}}(164 \mathrm{~mm})$ compared to the allowable values (Table 2).

It can also be noted that at $W_{\mathrm{c}}$ of $125 \mathrm{~mm}$, the maximum $q$ that can be carried by the unpiled raft is $129 \mathrm{kPa}$ for $t_{\mathrm{r}}$ of $1.5 \mathrm{~m}$. Therefore, the piles have to be added to the raft so as to reduce the settlements and to enhance the load-bearing capacity of the unpiled raft. The effects of different parameter such as $L_{\mathrm{p}}, S_{\mathrm{p}}, d_{\mathrm{p}}$, and $N_{\mathrm{p}}$ on the settlement and loadbearing behavior were studied through by 3-D numerical modeling. Figure 3 shows the typical layout of piled raft foundation for $3 \times 3$ pile group. The details of different small piled raft configurations $\left(B_{\mathrm{r}}<L_{\mathrm{p}}\right)$ included in this study are tabulated in Table 3.

The purpose of the parametric study is to achieve the optimization of $L_{\mathrm{p}}, S_{\mathrm{p}}, d_{\mathrm{p}}$, and $N_{\mathrm{p}}$ on the basis of settlement criteria and the bearing capacity criteria. The results are plotted in terms of settlement ratio, load-settlement behavior, and percentage load carried by the piles.

\section{Results and discussion}

\section{Check for settlement criteria}

\section{Effect of pile length $\left(L_{p}\right)$}

The effect of $L_{\mathrm{p}}$ on the $W_{\text {ratio }}$ for different pile group configurations is presented in Fig. 4. For any pile group, the pile lengths that satisfy the settlement criterion are found to be below the horizontal line with arrow head drawn at $W_{\text {ratio }}$ or $\Delta W_{\text {ratio }}$ of 1 . It can be observed that with increase in $L_{\mathrm{p}} / d_{\mathrm{p}}$ ratio from 15 to 50 , the $W_{\text {ratio }}$ decreased for any

Table 2 Bearing capacity and settlements for unpiled raft $\left(t_{\mathrm{r}}=1.5 \mathrm{~m}\right)$

\begin{tabular}{|c|c|c|c|c|c|}
\hline \multirow[t]{2}{*}{$q(\mathrm{kPa})$} & \multirow[t]{2}{*}{$\begin{array}{l}q_{\mathrm{s}}(\mathrm{kPa}) \text { as per } \\
\text { IS 6403-1981 }\end{array}$} & \multicolumn{2}{|c|}{$\begin{array}{l}\text { Allowable settlements as } \\
\text { per IS 1904-1986 (mm) }\end{array}$} & \multicolumn{2}{|c|}{$\begin{array}{l}\text { Measured } \\
\text { settlements } \\
\text { using } \\
\text { PLAXIS } \\
\text { 3-D (mm) }\end{array}$} \\
\hline & & $A M S$ & $A M D S$ & $W_{\mathrm{c}}$ & $W_{\mathrm{c}-\mathrm{e}}$ \\
\hline 150 & 66.8 & 125 & $49.5\left(0.0033 * B_{\mathrm{r}}\right)$ & 913 & 164 \\
\hline
\end{tabular}
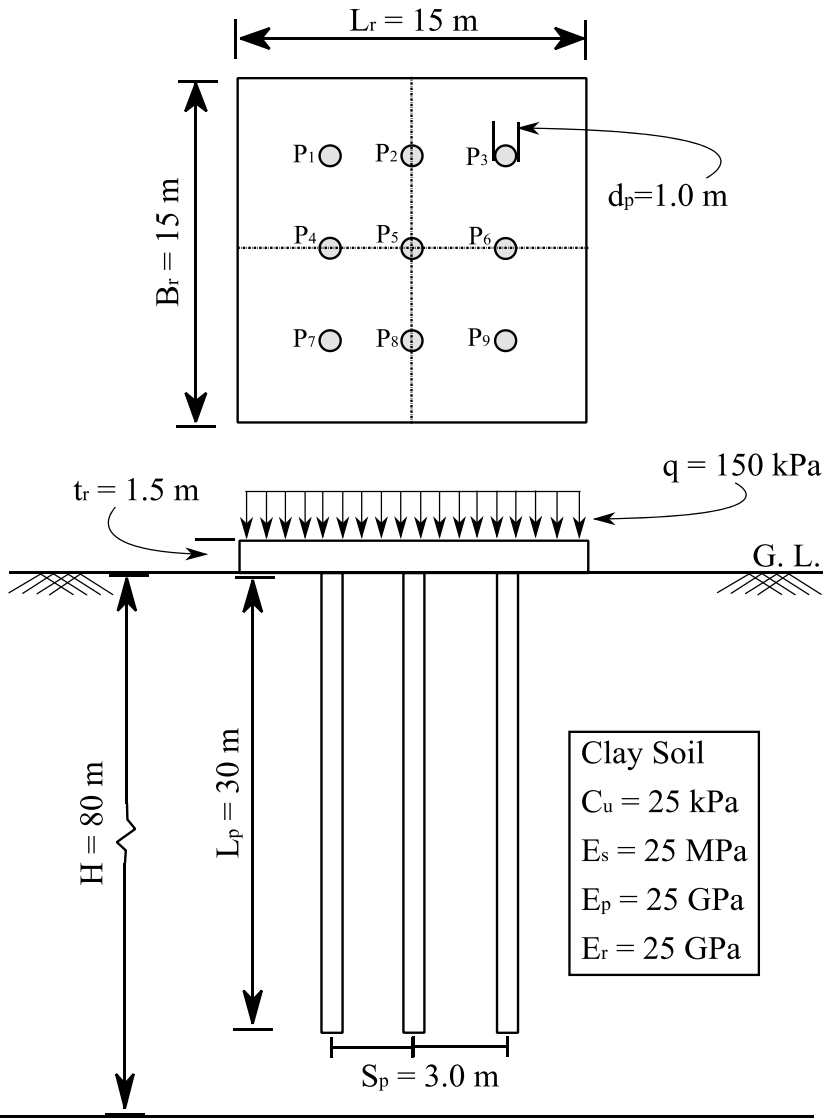

Fig. 3 Typical layout of piled raft foundation with $3 \times 3$ pile group

configuration. Moreover, with increasing $S_{\mathrm{p}}$, the pile group action might be diminishing and due to which the $W_{\text {ratio }}$ decreased. Thus, for $2 \times 2$ pile group, the required minimum $L_{\mathrm{p}}$ was $20 \mathrm{~m}$ for pile spacings of $4 \mathrm{~m}$ and $5 \mathrm{~m}$, and the corresponding total length of pile $\left(L_{\text {ptotal }}\right)$ was $80 \mathrm{~m}$. Similarly, for $4 \times 4$ pile group, the minimum $L_{\mathrm{p}}$ that satisfied the settlement criterion was $15 \mathrm{~m}$ with $S_{\mathrm{p}}$ of $4 \mathrm{~m}$, and the corresponding $L_{\text {ptotal }}$ was $240 \mathrm{~m}$. Therefore, a minimum of four piles with $L_{\text {ptotal }}$ of $80 \mathrm{~m}\left(L_{\mathrm{p}}=20 \mathrm{~m}\right.$ and $\left.N_{\mathrm{p}}=4\right)$ and $S_{\mathrm{p}}$ of $4 \mathrm{~m}$ was sufficient to satisfy the $W_{\text {ratio }}$ criteria. Seo et al. (2003) carried the parametric study of the piled raft by PLAXIS 2-D software and reported that the total settlement of piled raft in clay soil decreased as the pile length increased. Therefore, the finding of the present study is consistent with the reported results.

Table 3 Details of different piled raft configurations

\begin{tabular}{lll}
\hline Series & Pile group & Parametric values $(\mathrm{m})$ \\
\hline 1 & $2 \times 2$ & $L_{\mathrm{p}}=15,20,30,40,50$ \\
2 & $3 \times 3$ & $S_{\mathrm{p}}=3,4,5$ \\
3 & $4 \times 4$ & $d_{\mathrm{p}}=0.5,1.0,1.5$ \\
\hline
\end{tabular}




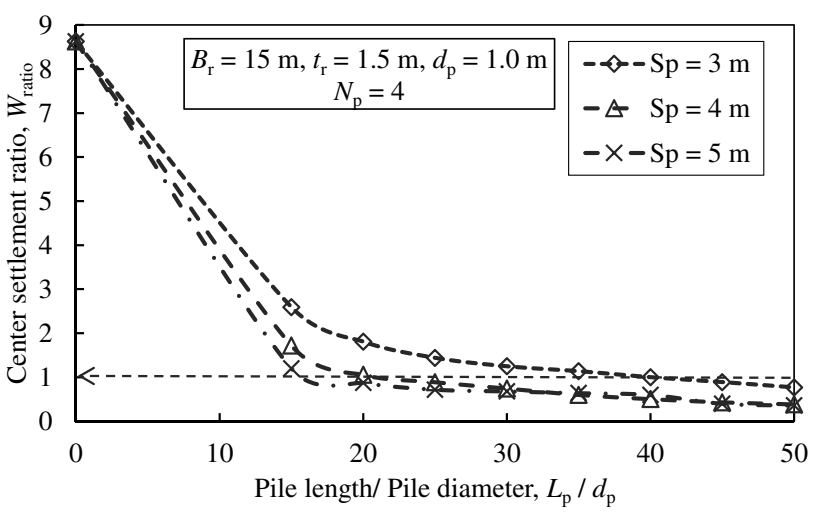

(a)

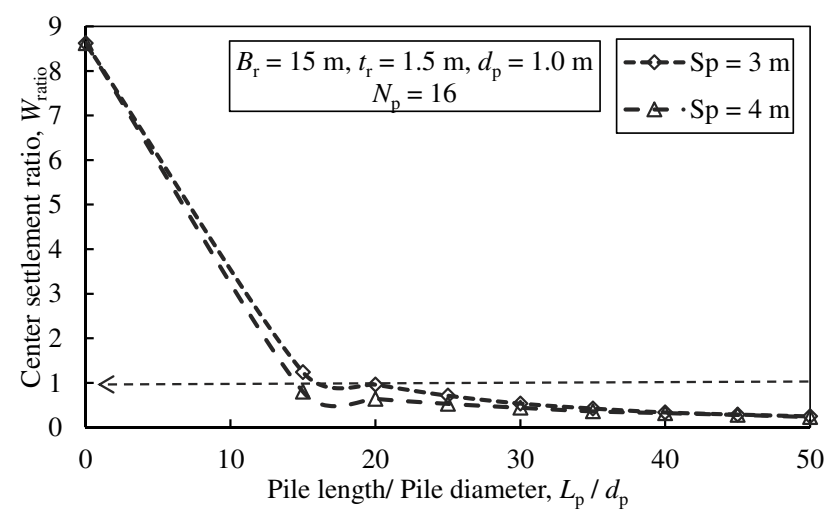

(b)

Fig. 4 Center settlement ratio versus $L_{\mathrm{p}} / d_{\mathrm{p}}$ ratio: a $2 \times 2$ pile group and $\mathbf{b} 4 \times 4$ pile group

The effect of $L_{\mathrm{p}}$ on the load-settlement behavior of piled raft is shown in Fig. 5. It can be observed that the load-bearing capacity of the piled raft increased with increase in $L_{\mathrm{p}}$, and the $W_{\mathrm{c}}$ measured at the center point on the raft decreased with the increase in $L_{\mathrm{p}}$. Sinha and Hanna (2016) reported that the load carrying capacity of the piled raft increased and the settlement measured at the center point on the raft decreased with the increase of the pile length. The maximum $W_{\mathrm{c}}$ values at $150 \mathrm{kPa}$ load for $15 \mathrm{~m}$ pile length were $273 \mathrm{~mm}$, $132 \mathrm{~mm}$, and $107 \mathrm{~mm}$, respectively, for the $2 \times 2,3 \times 3$, and $4 \times 4$ pile groups.

\section{Effect of pile spacing $\left(S_{p}\right)$}

The effect of $S_{\mathrm{p}}$ on the $W_{\text {ratio }}$ for different pile group configurations is shown in Fig. 6. For any pile group, the pile spacings that satisfy the settlement criterion are found to be below the horizontal line with arrow head drawn at $W_{\text {ratio }}$ or $\Delta W_{\text {ratio }}$ of 1 . It can be seen that with increase in $S_{\mathrm{p}} / d_{\mathrm{p}}$ ratio from 3 to $5, W_{\text {ratio }}$ decreased for the $4 \times 4$ configuration. As the $S_{\mathrm{p}}$ increased, there might be uniform distribution of load among the piles, due to which $W_{\text {ratio }}$ decreased. However, for the $2 \times 2$ configuration, the $W_{\text {ratio }}$ remained constant as $S_{\mathrm{p}} / d_{\mathrm{p}}$

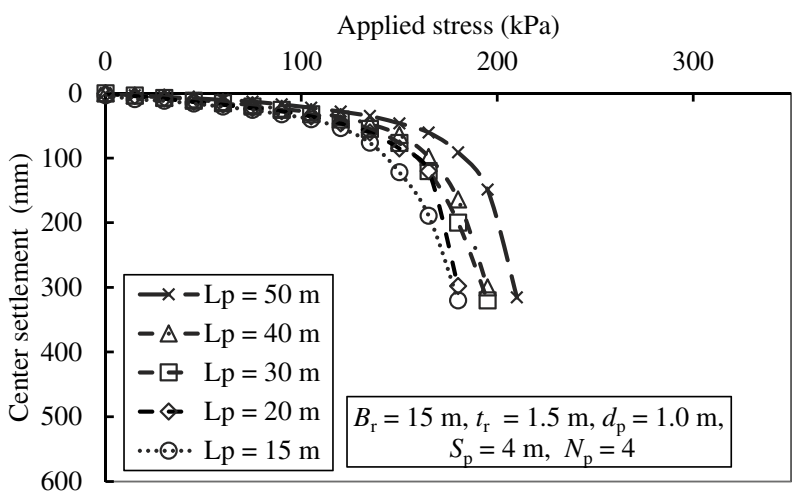

(a)

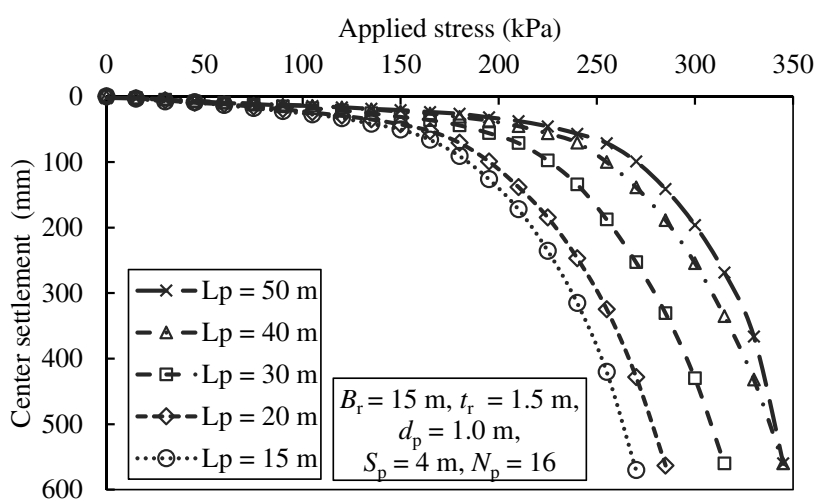

(b)

Fig. 5 Load-settlement behavior for different pile lengths: a $2 \times 2$ pile group and $\mathbf{b} 4 \times 4$ pile group

ratio changed from 3 to 4 , and thereafter, the $W_{\text {ratio }}$ decreased at $S_{\mathrm{p}} / d_{\mathrm{p}}$ ratio of 5 . This behavior might be attributed to the transition of pile group action to the individual pile action. For the $2 \times 2$ pile group, the pile spacings of $3 \mathrm{~m}$ and $4 \mathrm{~m}$ satisfied the settlement criteria for pile lengths of 40 and $50 \mathrm{~m}$. Similarly, for $4 \times 4$ pile group, the $S_{\mathrm{p}}$ of $4 \mathrm{~m}$ satisfied the settlement criteria for $L_{\mathrm{p}}$ of $30 \mathrm{~m}$. Therefore, a minimum of four piles with $L_{\text {ptotal }}$ of $160 \mathrm{~m}\left(L_{\mathrm{p}}=40 \mathrm{~m}\right.$ and $\left.N_{\mathrm{p}}=4\right)$ and $S_{\mathrm{p}}$ of $4 \mathrm{~m}$ was sufficient to satisfy the $W_{\text {ratio }}$ criteria.

\section{Effect of number of piles $\left(\mathrm{N}_{\mathrm{p}}\right)$}

The effect of the $N_{\mathrm{p}}$ on the $W_{\text {ratio }}$ of piled raft foundations is shown in Fig. 7. The total numbers of piles that satisfy the settlement criterion are found to be below the horizontal line with arrow head drawn at $W_{\text {ratio }}$ or $\Delta W_{\text {ratio }}$ of 1 . From this figure, it can be observed that with increase in $N_{\mathrm{p}}$ from 4 to $16, W_{\text {ratio }}$ decreased. Thus, a minimum nine piles with $L_{\text {ptotal }}$ of $135 \mathrm{~m}\left(L_{\mathrm{p}}=15 \mathrm{~m}\right.$ and $\left.N_{\mathrm{p}}=9\right)$ was sufficient to satisfy the $W_{\text {ratio }}$ criteria.

Figure 8 shows the variation of $\Delta W_{\text {ratio }}$ versus $N_{\mathrm{p}}$ for different pile lengths. It can be seen that with increase in $N_{\mathrm{p}}$ from 4 to $16, \Delta W_{\text {ratio }}$ decreased initially, and then it 


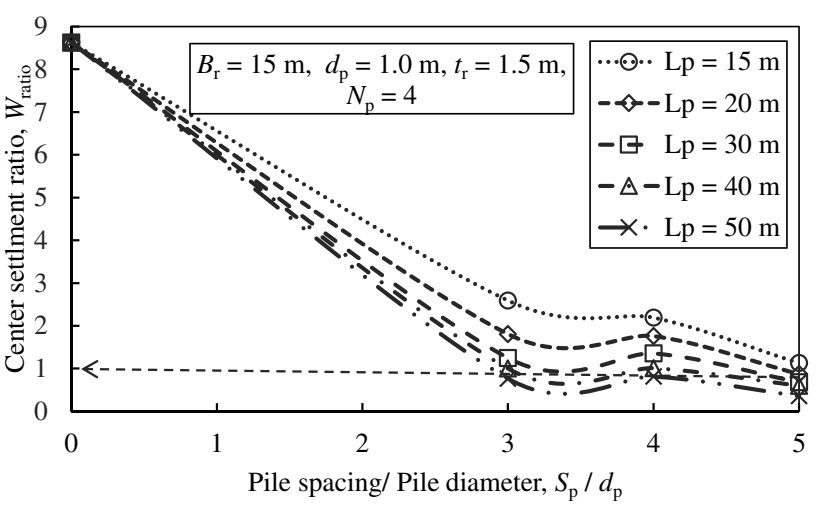

(a)

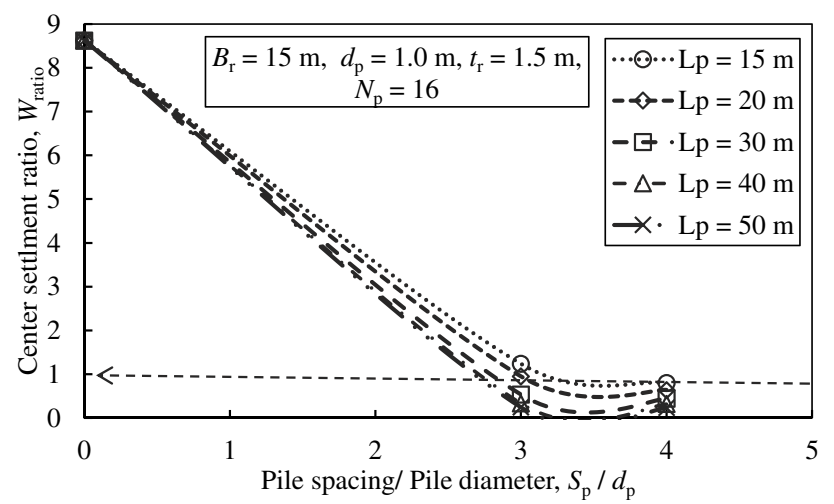

(b)

Fig. 6 Center settlement ratio versus $S_{\mathrm{p}} / d_{\mathrm{p}}$ ratio: a $2 \times 2$ pile group and $\mathbf{b} 4 \times 4$ pile group

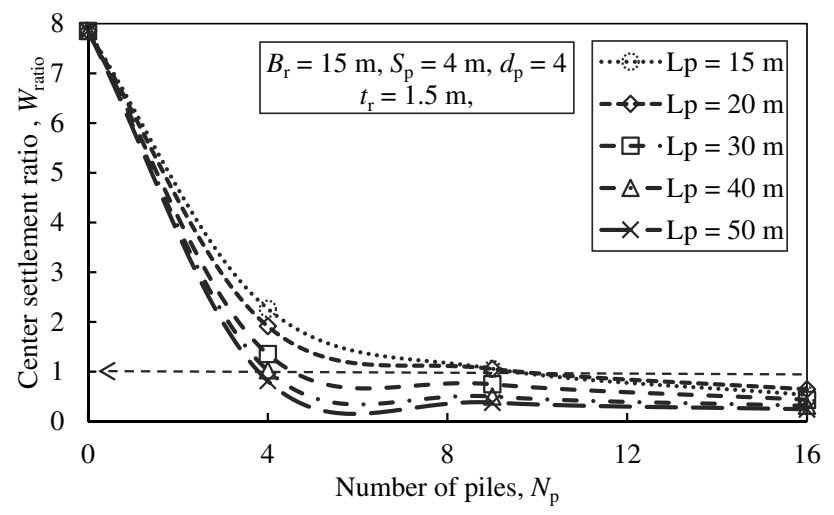

Fig. 7 Center settlement ratio versus number of piles

remain constant for $2 \times 2$ pile group. Moreover, the similar trends were observed for the other pile groups $(3 \times 3$ and $4 \times 4)$. Therefore, a minimum of $15 \mathrm{~m} L_{\mathrm{p}}$ with any $N_{\mathrm{p}}$ can be used to satisfy the $\Delta W_{\text {ratio }}$ criterion. Thus, a minimum of four piles with $L_{\text {ptotal }}$ of $60 \mathrm{~m}\left(L_{\mathrm{p}}=15 \mathrm{~m}\right.$ and $\left.N_{\mathrm{p}}=4\right)$ was sufficient to satisfy the $\Delta W_{\text {ratio }}$ criteria.

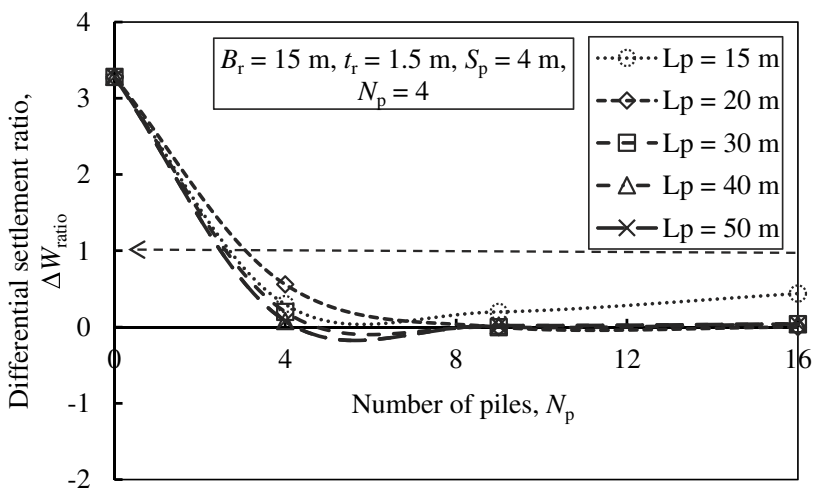

Fig. 8 Differential settlement ratio versus number of piles

\section{Check for bearing capacity}

\section{Effect of pile length $\left(L_{p}\right)$}

Table 4 shows the comparison of load carried by individual piles $\left(q_{\mathrm{p}}\right)$ and the load carried by piles as a percentage of its ultimate capacities $\left(q_{\% \mathrm{u}}\right)$ for different pile lengths. It can be noted that the corner pile carried the highest load followed by the edge pile and the center pile. Moreover, it was also observed that all the piles with different lengths were loaded to almost $\sim 50 \%$ of its ultimate capacity. The ultimate capacity $\left(q_{\mathrm{up}}\right)$ of a pile of $L_{\mathrm{p}}$ equal to $15 \mathrm{~m}, 20 \mathrm{~m}$, $30 \mathrm{~m}, 40 \mathrm{~m}$, and $50 \mathrm{~m}$ with $1 \mathrm{~m} d_{\mathrm{p}}$ was calculated to be $1354.12 \mathrm{kPa}, 1746.62 \mathrm{kPa}, 2531.62 \mathrm{kPa}, 3316.62 \mathrm{kPa}$, and $4101.62 \mathrm{kPa}$, respectively. The $q_{\text {up }}$ for a $L_{\mathrm{p}}$ of $30 \mathrm{~m}$ and $1 \mathrm{~m}$ $d_{\mathrm{p}}$ is illustrated as follow.

$q_{u p}=\left(c_{u} N_{c} A_{b}+\alpha c_{u} A_{s}\right)$

w h e r e $\quad c_{u}=25 \mathrm{kPa}, \quad N_{c}=9$, $A_{b}=$ area of base of pile $=0.785 \times 1^{2}=0.785 \mathrm{~m}^{2}$,

$\alpha=$ Adhesionfactor $=1$

$A_{s}=$ surface area of pile $=3.14 \times 1 \times 30=94.2 \mathrm{~m}^{2}$,

$\therefore q_{u p}=(25 \times 9 \times 0.785+1 \times 25 \times 94.2)=2531.62 \mathrm{kPa}$

\section{Effect of pile spacing $\left(S_{p}\right)$}

Table 5 shows the comparison of $q_{\mathrm{p}}$ and $q_{\% \mathrm{u}}$ for different pile spacings. It can be seen that for any $S_{\mathrm{p}}$, the load carried by different piles increased in the following order: corner pile, edge pile, and center pile. Moreover, it was 
Table 4 Comparison of $q_{\mathrm{p}}$ and $q_{\% \mathrm{u}}$ for different pile lengths $\left(S_{\mathrm{p}}=4 \mathrm{~m}, d_{\mathrm{p}}=1.0 \mathrm{~m}\right.$, and $N_{\mathrm{p}}=9$ )

\begin{tabular}{lllllllllll}
\hline$L_{\mathrm{p}}(\mathrm{m})$ & Load & $P_{1}$ & $P_{2}$ & $P_{3}$ & $P_{4}$ & $P_{5}$ & $P_{6}$ & $P_{7}$ & $P_{8}$ & $P_{9}$ \\
\hline 15 & $q_{p}(\mathrm{kN})$ & 713 & 647 & 711 & 689 & 709 & 683 & 711 & 710 & 709 \\
& $q_{\% \mathrm{u}}(\%)$ & 53 & 48 & 53 & 51 & 52 & 50 & 52 & 52 & 52 \\
20 & $q_{p}(\mathrm{kN})$ & 894 & 847 & 928 & 926 & 884 & 899 & 925 & 886 & 927 \\
& $q_{\% \mathrm{u}}(\%)$ & 51 & 48 & 53 & 52 & 50 & 51 & 52 & 50 & 53 \\
30 & $q_{p}(\mathrm{kN})$ & 1278 & 1258 & 1240 & 1224 & 1243 & 1238 & 1248 & 1305 & 1280 \\
& $q_{\% \mathrm{u}}(\%)$ & 50 & 50 & 49 & 48 & 49 & 49 & 49 & 52 & 51 \\
40 & $q_{p}(\mathrm{kN})$ & 1659 & 1608 & 1653 & 1591 & 1591 & 1622 & 1691 & 1608 & 1658 \\
& $q_{\% \mathrm{u}}(\%)$ & 49 & 48 & 49 & 47 & 47 & 48 & 50 & 48 & 49 \\
50 & $q_{p}(\mathrm{kN})$ & 2015 & 1923 & 1943 & 2010 & 1994 & 1892 & 1837 & 1935 & 1990 \\
& $q_{\% \mathrm{u}}(\%)$ & 49 & 47 & 47 & 49 & 49 & 46 & 45 & 47 & 49 \\
\hline
\end{tabular}

Table 5 Comparison of $q_{\mathrm{p}}$ and $q_{\% \mathrm{u}}$ for different pile spacings $\left(L_{\mathrm{p}}=30 \mathrm{~m}, d_{\mathrm{p}}=1 \mathrm{~m}\right.$, and $\left.N_{\mathrm{p}}=9\right)$

\begin{tabular}{lllllllllll}
\hline$S_{\mathrm{p}}(\mathrm{m})$ & Load & $P_{1}$ & $P_{2}$ & $P_{3}$ & $P_{4}$ & $P_{5}$ & $P_{6}$ & $P_{7}$ & $P_{8}$ & $P_{9}$ \\
\hline 3 & $q_{p}(\mathrm{kN})$ & 1288 & 1210 & 1249 & 1236 & 1216 & 1187 & 1231 & 1230 & 1260 \\
& $q_{\% \mathrm{u}}(\%)$ & 51 & 48 & 49 & 49 & 48 & 47 & 49 & 49 & 50 \\
4 & $q_{p}(\mathrm{kN})$ & 1258 & 1278 & 1240 & 1224 & 1243 & 1238 & 1248 & 1305 & 1280 \\
& $q_{\% \mathrm{u}}(\%)$ & 50 & 50 & 49 & 48 & 49 & 49 & 49 & 52 & 51 \\
5 & $q_{p}(\mathrm{kN})$ & 1292 & 1319 & 1311 & 1267 & 1229 & 1197 & 1329 & 1324 & 1324 \\
& $q_{\% \mathrm{u}}(\%)$ & 51 & 52 & 52 & 50 & 49 & 47 & 52 & 52 & 52 \\
\hline
\end{tabular}

Table 6 Comparison of $q_{\mathrm{p}}$ and $q_{\% \mathrm{u}}$ for different pile diameters $\left(L_{\mathrm{p}}=30 \mathrm{~m}, S_{\mathrm{p}}=4 \mathrm{~m}\right.$, and $\left.N_{\mathrm{p}}=9\right)$

\begin{tabular}{lllllllllll}
\hline$d_{\mathrm{p}}(\mathrm{m})$ & Load & $P_{1}$ & $P_{2}$ & $P_{3}$ & $P_{4}$ & $\mathrm{P}_{5}$ & $P_{6}$ & $P_{7}$ & $P_{8}$ & $P_{9}$ \\
\hline 0.5 & $q_{p}(\mathrm{kN})$ & 765 & 766 & 769 & 762 & 771 & 772 & 769 & 773 & 774 \\
& $q_{\% \mathrm{u}}(\%)$ & 63 & 63 & 63 & 62 & 63 & 63 & 63 & 63 & 63 \\
1 & $q_{p}(\mathrm{kN})$ & 1258 & 1278 & 1240 & 1224 & 1243 & 1238 & 1248 & 1305 & 1280 \\
& $q_{\% \mathrm{u}}(\%)$ & 50 & 50 & 49 & 48 & 49 & 49 & 49 & 52 & 51 \\
1.5 & $q_{p}(\mathrm{kN})$ & 1484 & 1512 & 1510 & 1481 & 1496 & 1500 & 1561 & 1460 & 1502 \\
& $q_{\% \mathrm{u}}(\%)$ & 38 & 38 & 38 & 38 & 38 & 38 & 40 & 37 & 38 \\
\hline
\end{tabular}

also observed that with increase in $S_{\mathrm{p}}$, the $q_{\% \mathrm{u}}$ remained constant approximately.

\section{Effect of pile diameter $\left(d_{p}\right)$}

The effect of pile diameter on percentage load carried by piles is shown in Table 6 . It can be seen that for every $d_{\mathrm{p}}$, the load carried by different piles increased in the following order: corner pile, edge pile, and center pile. In addition to this, it was noted that with increase in $d_{\mathrm{p}}$ at constant $L_{\mathrm{p}}$, the $q \%$ decreased.

\section{Effect of number of piles $\left(\mathrm{N}_{\mathrm{p}}\right)$}

Figure 9 shows the variation of percentage load carried by the piles versus the number of piles. As the $N_{\mathrm{p}}$ increased, the percentage load carried by the piles increased for all $L_{\mathrm{p}}$. The load carried by $30 \mathrm{~m}$ pile varies from 14.40 to $54.69 \%$ as the $N_{\mathrm{p}}$ increased from 4 to 16 . El-Garhy et al.

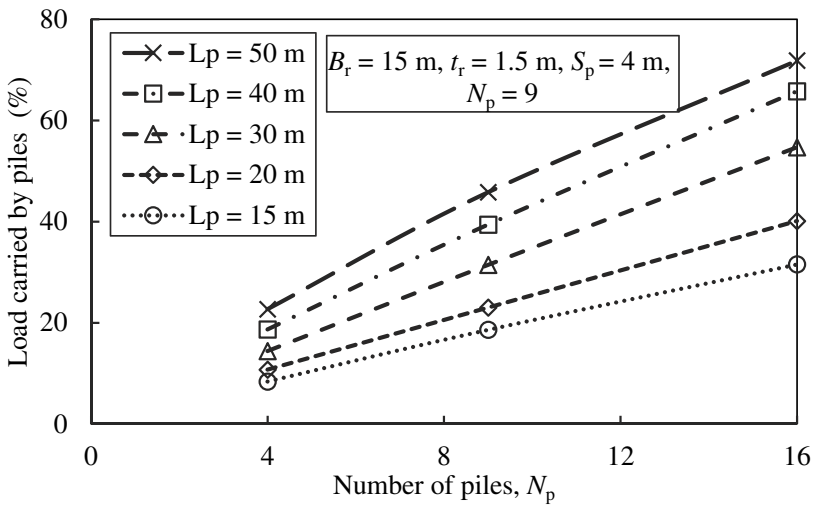

Fig. 9 Percentage load carried by piles versus $N_{\mathrm{p}}$ 
(2013) reported that the proportion of load carried by piles increased as the number of piles increased, and inversely the proportion of load carried by raft decreased as the number of piles increased.

Thus, the piled raft configuration which satisfied the settlements criteria ( $W_{\text {ratio }}$ and $\Delta W_{\text {ratio }}$ ) may or may not provide the necessary $q_{\mathrm{s}}=67 \mathrm{kPa}$, and hence, it is important to check the possible configurations which will satisfy both the criteria. Table 7 shows the total load carried by the piles $\left(q_{\text {ptotal }}\right)$, load carried by the raft $\left(q_{\mathrm{r}}\right)$, measured safe bearing capacity of raft from PLAXIS 3-D $\left(q_{\mathrm{m}}\right)$, and $W_{\mathrm{c}}$ for different pile groups with variations of $S_{\mathrm{p}}$, and $N_{\mathrm{p}}$. It can be seen that both the settlement criteria and bearing capacity criteria can be fulfilled for a minimum $L_{\text {ptotal }}$ is equal to $480 \mathrm{~m}\left(L_{\mathrm{p}}=30 \mathrm{~m}, N_{\mathrm{p}}=16\right)$. Therefore, out of the piled raft configuration which satisfied both the settlement and bearing capacity criteria can be selected as the optimum configuration for the present study. Thus, based on the settlements criteria $\left(W_{\text {ratio }}\right.$ and $\left.\Delta W_{\text {ratio }}\right)$ and bearing capacity criteria $\left(q_{\mathrm{m}} \leq 67 \mathrm{kPa}\right)$, the piled raft configuration with $L_{\mathrm{p}}=30 \mathrm{~m}, S_{\mathrm{p}}=4 \mathrm{~m}, d_{\mathrm{p}}=1 \mathrm{~m}, N_{\mathrm{p}}=16$, and $t_{\mathrm{r}}=1.5$ may be selected as the optimum configuration for the present study.

\section{Bending moment $(\mathrm{M})$ and shear force $(\tau)$}

The maximum bending moment $\left(M_{\max }\right)$ and maximum shear force $\left(\tau_{\max }\right)$ developed in the raft foundations are considered as crucial entity for designing the required reinforcing steel. The magnitudes of $M_{\max }$ and $\tau_{\max }$ in raft vary with variation of $L_{\mathrm{p}}, S_{\mathrm{p}}, d_{\mathrm{p}}$, and $N_{\mathrm{p}}$. Table 8 shows the $M_{\max }$ and $\tau_{\max }$ for different piled raft parameters. It can be seen that, with increase in $L_{\mathrm{p}}$, the $M_{\max }$ decreased and $\tau_{\max }$ increased. Moreover, with increase in $S_{\mathrm{p}}, d_{\mathrm{p}}$, and $N_{\mathrm{p}}$, the $M_{\max }$ and $\tau_{\max }$ increased. Poulos (2001b) reported that the maximum bending moment in the raft increases with increases in raft thickness and number of piles. Therefore, the optimum parameters for the piled raft foundation can be selected efficiently with the consideration of $M_{\max }$ and $\tau_{\max }$ while designing the piled raft foundation.
Table 8 Effect of different piled raft parameters on $\tau_{\max }$ and $M_{\max }$

\begin{tabular}{llll}
\hline Parameters & Values $(\mathrm{m})$ & $M_{\max }(\mathrm{kN}-\mathrm{m} / \mathrm{m})$ & $\tau_{\max }(\mathrm{kN} / \mathrm{m})$ \\
\hline$L_{\mathrm{p}}(\mathrm{m})$ & 15 & 668 & 287 \\
& 20 & 559 & 259 \\
& 30 & 377 & 299 \\
& 40 & 291 & 379 \\
& 50 & 212 & 443 \\
$S_{\mathrm{p}}(\mathrm{m})$ & 3 & 160 & 279 \\
& 4 & 377 & 299 \\
& 5 & 616 & 327 \\
$d_{\mathrm{p}}(\mathrm{m})$ & 0.5 & 346 & 224 \\
& 1 & 377 & 299 \\
& 1.5 & 527 & 411 \\
$N_{\mathrm{p}}$ & 4 & 260 & 257 \\
& 9 & 377 & 299 \\
& 16 & 771 & 488 \\
\hline
\end{tabular}

\section{Conclusions}

The study considered a framework for the optimum design in terms of maximum settlement, differential settlements, and load-bearing capacity of piled raft. Based on the results, following conclusions are presented.

1. With increase in $L_{\mathrm{p}} / d_{\mathrm{p}}$ ratio from 15 to 50 by keeping $d_{\mathrm{p}}=1 \mathrm{~m}$, the $W_{\text {ratio }}$ and $\Delta W_{\text {ratio }}$ decreases for all the pile group arrangements; moreover, the percentage load carried by the piles increases. The minimum of four piles with $L_{\text {ptotal }}$ of $80 \mathrm{~m}\left(L_{\mathrm{p}}=20 \mathrm{~m}\right.$ and $\left.N_{\mathrm{p}}=4\right)$ and $S_{\mathrm{p}}$ of $4 \mathrm{~m}$ is sufficient to satisfy the $W_{\text {ratio }}$ criteria. Similarly a minimum of four piles with $L_{\text {ptotal }}$ of $60 \mathrm{~m}\left(L_{\mathrm{p}}=15 \mathrm{~m}\right.$ and $\left.N_{\mathrm{p}}=4\right)$ is sufficient to satisfy the $\Delta W_{\text {ratio }}$ criteria. The load-bearing capacity of piled raft increases with increase in $L_{\mathrm{p}}$ and the $W_{\mathrm{c}}$ decreases with the increase in $L_{\mathrm{p}}$. The $W_{\mathrm{c}}$ is lower for a greater $L_{\mathrm{p}}$ for any pile group. For any $L_{\mathrm{p}}$, the largest pile loads are concentrated at the corner of the pile group, and it decrease towards the center of the group.
Table 7 Load intensity and center settlement below the raft for different piled raft configuration

\begin{tabular}{|c|c|c|c|c|c|c|c|c|c|}
\hline$d_{\mathrm{p}}(\mathrm{m})$ & $t_{\mathrm{r}}(\mathrm{m})$ & $S_{\mathrm{p}}(\mathrm{m})$ & $N_{\mathrm{p}}$ & $L_{\mathrm{p}}(\mathrm{m})$ & $L_{\text {ptotal }}(\mathrm{m})$ & $q_{\text {ptotal }}(\mathrm{kN})$ & $q_{\mathrm{r}}(\mathrm{kN})$ & $q_{\mathrm{m}}(\mathrm{kPa})$ & $W_{c}(\mathrm{~mm})$ \\
\hline \multirow[t]{7}{*}{1} & \multirow[t]{7}{*}{1.5} & \multirow[t]{3}{*}{3} & $3 \times 3$ & 50 & 450 & 16,390 & 17,360 & $79.66\left(>q_{\mathrm{s}}\right)$ & $49(<A M S)$ \\
\hline & & & $4 \times 4$ & 30 & 480 & 19,249 & 14,501 & $66.54\left(<q_{\mathrm{s}}\right)$ & $67(<A M S)$ \\
\hline & & & $5 \times 5$ & 20 & 500 & 21,072 & 12,678 & $58.17\left(<q_{\mathrm{s}}\right)$ & $78(<A M S)$ \\
\hline & & \multirow[t]{3}{*}{4} & $3 \times 3$ & 50 & 450 & 17,539 & 16,211 & $74.39\left(>q_{\mathrm{s}}\right)$ & $48(<A M S)$ \\
\hline & & & $4 \times 4$ & 20 & 320 & 13,974 & 19,776 & $90.74\left(>q_{\mathrm{s}}\right)$ & $80(<A M S)$ \\
\hline & & & & 30 & 480 & 19,963 & 13,787 & $63.26\left(<q_{\mathrm{s}}\right)$ & $55(<A M S)$ \\
\hline & & 5 & $3 \times 3$ & 50 & 450 & 18,429 & 15,321 & $70.30\left(>q_{\mathrm{s}}\right)$ & $47(<A M S)$ \\
\hline
\end{tabular}


2. With increase in $S_{\mathrm{p}} / d_{\mathrm{p}}$ from 3 to 5 , the $W_{\text {ratio }}$ decreases for all pile groups of any $L_{\mathrm{p}}$; moreover, the percentage load carried by the piles increases. However, the increase is noted to be minimal beyond $4 \mathrm{~m}$ spacing. A minimum of four piles with $L_{\text {ptotal }}$ of $160 \mathrm{~m}\left(L_{\mathrm{p}}=40 \mathrm{~m}\right.$ and $\left.N_{\mathrm{p}}=4\right)$ and $S_{\mathrm{p}}$ of $4 \mathrm{~m}$ is sufficient to satisfy the $W_{\text {ratio }}$ criteria. The load-bearing capacity of piled raft increases with increase in $S_{\mathrm{p}}$ and the $W_{\mathrm{c}}$ decreases with the increase in $S_{\mathrm{p}}$. For any $S_{\mathrm{p}}$, the largest pile loads are concentrated at the corner of the pile group, and it decrease towards the center of the group.

3. With increase in $N_{\mathrm{p}}$, the $W_{\text {ratio }}$ decreases and the percentage load carried by the piles increases. Also as the $N_{\mathrm{p}}$ increases, the $\Delta W_{\text {ratio }}$ decreases initially and then remains constant for all pile groups. A minimum nine piles with $L_{\text {ptotal }}$ of $135 \mathrm{~m}\left(L_{\mathrm{p}}=15 \mathrm{~m}\right.$ and $\left.N_{\mathrm{p}}=9\right)$ is sufficient to satisfy the $W_{\text {ratio }}$ criteria. Similarly, a minimum of four piles with $L_{\text {ptotal }}$ of $60 \mathrm{~m}\left(L_{\mathrm{p}}=15 \mathrm{~m}\right.$ and $\left.N_{\mathrm{p}}=4\right)$ is sufficient to satisfy the $\Delta W_{\text {ratio }}$ criteria. The load-bearing capacity of piled raft increases with increase in $N_{\mathrm{p}}$ and the $W_{\mathrm{c}}$ of the raft decrease with the increase in $N_{\mathrm{p}}$.

4. Based on the settlements criteria $\left(W_{\text {ratio }}\right.$ and $\left.\Delta W_{\text {ratio }}\right)$ and bearing capacity criteria $\left(q_{\mathrm{m}} \leq 67 \mathrm{kPa}\right)$, the piled raft configuration with $L_{\mathrm{p}}=30 \mathrm{~m}, S_{\mathrm{p}}=4 \mathrm{~m}, d_{\mathrm{p}}=1 \mathrm{~m}$, and $N_{\mathrm{p}}=16$ may be selected as the optimum parameter for the present study.

5. The $\tau$ and $M$ are observed to be higher in corner pile and they decreases towards the center pile. With increase in $L_{\mathrm{p}}$, the $M_{\max }$ decreases and $\tau_{\max }$ increases. Moreover, with increase in $S_{\mathrm{p}}, d_{\mathrm{p}}$, and $N_{\mathrm{p}}$, the, $M_{\max }$ and $\tau_{\max }$ increases.

\section{Declarations}

Conflict of interest The authors declare that they have no competing interests.

Open Access This article is licensed under a Creative Commons Attribution 4.0 International License, which permits use, sharing, adaptation, distribution and reproduction in any medium or format, as long as you give appropriate credit to the original author(s) and the source, provide a link to the Creative Commons licence, and indicate if changes were made. The images or other third party material in this article are included in the article's Creative Commons licence, unless indicated otherwise in a credit line to the material. If material is not included in the article's Creative Commons licence and your intended use is not permitted by statutory regulation or exceeds the permitted use, you will need to obtain permission directly from the copyright holder. To view a copy of this licence, visit http://creativecommons.org/licenses/by/4.0/.
Ahmed M, Mohamed MH, Mallick J, Hasan MA (2014) 3D-Analysis of soil-foundation-structure interaction in layered soil. Open J Civ Eng 4(4):373. https://doi.org/10.4236/ojce.2014.44032

Cho J, Lee J, Jeong S, Lee J (2012) The settlement behavior of piled raft in clay soils Ocean Eng 153-163https://doi.org/10.1016/j. oceaneng.2012.06.003

El-Garhy B, Galil AA, Youssef AF, Raia MA (2013) Behavior of raft on settlement reducing piles: experimental model study. J Rock Mech Geotech Eng 5(5):389-399. https://doi.org/10.1016/j.jrmge. 2013.07.005

IS 1904-1986 Code of practice for design and construction of foundations in soils. Bureau of Indian Standards, New Delhi, India

IS 6403-1981 Code of practice for determination of bearing capacity of shallow foundations. Bureau of Indian Standards, New Delhi, India

Johari A, Hosseini SM, Keshavarz A (2017) Reliability analysis of seismic bearing capacity of strip footing by stochastic slip lines method. Comput Geotech 91:203-217

Johari A, Sabzi A (2017) Reliability analysis of foundation settlement by stochastic response surface and random finite element method. Scientia Iranica 24(6):2741-2751

Johari A, Talebi A (2021) Stochastic analysis of piled-raft foundations using the random finite-element method. Int $\mathbf{J}$ Geomech 21(4):04021020

Lee J, Kim Y, Jeong S (2010) Three dimensional analysis of bearing behavior of piled raft on soft clay. Comput Geotech 37:103-114. https://doi.org/10.1016/j.compgeo.2009.07.009

Maharaj DK, Gandhi SR (2004) Non-linear finite element analysis of piled-raft foundations. Proc Inst Civ Eng Geotech Eng 157:107-113

Nguyen DDC, Kim DS, Jo SB (2014) Parametric Study for Optimal Design of Large Piled Raft Foundations on Sand. Comput Geotech 55:14-26. https://doi.org/10.1019/j.compgeo.2013.07.014

Oh EYN, Bui QM, Surarak C, Balasurbamaniam AS (2009) Investigation of the behavior of piled raft foundation in sand by numerical modelling. In: Proceedings of the 19th Offshore and Polar Engineering Conference, Japan, pp 1159-1162. https://doi.org/ 10.3233/978-1-60750-031-5-1159

Poulos HG (2001a) Piled raft foundations: design and applications. Geotechnique 51(1):95-113

Poulos HG, (2001b) Methods of analysis of piled raft foundations. A Report Prepared on Behalf of Technical Committee TC18 on Piled Foundations.

Russo G, Abagnara V, Poulos HG, Small JC (2013) Re-assessment of foundation settlement for the burjkhalifa Dubai Acta Geoechnica 3-15https://doi.org/10.1007/s11440-012-0193-4

Sales MM, Small JC, Poulos HG (2010) Compensated piled rafts in clayey soils: behaviour, measurements, and predictions. Can Geotech J 47(3):327-345. https://doi.org/10.1139/T09-106

Sanctis LD, Mandolini A (2006) Bearing capacity of the piled rafts on soft clays. J Geotech Geoenviron Eng ASCE 132:1600-1610. https://doi.org/10.1061/ASCE1090-02412006132:121600

Seo YK, Choi KS, Jeong SG, (2003) Design charts of piled raft foundations on soft clay. In: Proceedings of the 13th offshore and polar engineering conference, Hawaii, USA, pp 753-755

Sinha A, Hanna AM (2016) 3D Numerical model for piled raft foundation. Int J Geomech. https://doi.org/10.1061/(ASCE)GM.19435622.0000674

Viggiani C (2001) Analysis and design of piled raft foundations. First Arrigo Croce Lecture, Rivista Italiana Di Geotechnica, 47-75

\section{References}

Akl AY, Mansour MH, Moustafa HK (2014) Effect of changing configurations and lengths of piles on piled raft foundation behaviour. Civ Eng Urban Plan Int J 1(1) 